\title{
Treated Wastewater Impact on Rural Green Farm Life Cycle, Egypt
}

\author{
M.H. El-Awady ${ }^{*}$, N.M. Marzouk ${ }^{2}$, B.A. Bakry ${ }^{3}$, H.M. Abdel-Rahman ${ }^{4}$,A. Kenawy ${ }^{5}$ \\ ${ }^{1}$ Water Pollution Res. Dept., ${ }^{2}$ Vegetable Res. Dept., ${ }^{3}$ Crops Res. Dept., ${ }^{4}$ Genetics and \\ Cytology Dept., ${ }^{5}$ Hydrobiology Dept., National Research Centre, P.O. Box 12622, El- \\ Bohouth St., Dokki, Giza, Egypt.
}

\begin{abstract}
$\mathbf{T}$ REATED effluent from wastewater treatment plant (WWTP) offers significant water demand in all areas of activities in rural farm. This research evaluates the reuse of secondary treated wastewater (STWW) for irrigating crops, fresh vegetables and feeding fish farm. Physico-chemical, heavy metals and cytogenetic have been investigated. Intensive analyses of crops seeds, vegetables components, soil, dried sludge and fish organisms have been carried out. Results showed that the characteristics of secondary treated wastewater can be used for crops plantation and fish farming. Cytogenetic studies using Alliums' bio-tests were investigated. The concentrations of each: $\mathrm{Cr}, \mathrm{Pb}, \mathrm{Co}, \mathrm{Se}, \mathrm{Ni}, \mathrm{Cu}$, and $\mathrm{Zn}$ in STWW was less than $0.1 \mathrm{mg} / 1$. Carbon content, nitrogen, and phosphorous were: $6.0 ; 1.2$; and $0.1 \mathrm{mg} / 1$, respectively fulfilling the requirements $\mathrm{C}$ : N: P ratios for plant growth. Results showed also that the irrigated crops and vegetables exhibited good growth. Analyses of roots, stems, leaves, seeds and sludge showed metals concentrations were within the permissible range. Tilapia fish showed noticeable vitality. Parasitological examination of fish revealed no parasitic cysts detected in the skin, gills and intestine, respectively. It showed no bacterial strains isolated from fish tissues. Macroscopically parameters as root length and shape look normal and healthy, while microscopically parameters showed no change of mitotic index, RDR, phase index, chromosomal aberrations of the bioassay plant tissues and do not stimulate specific type of chromosomal aberrations as well as percentage of chromosomal aberrations. All studied parameters were found in normal limits when compared with control values. This indicated the efficiency of the treatment system; hence STWW has no mutagenicity or cytotoxicity effects. Examined parameters in this study were found in normal limits if compared with trigger levels of treated wastewater.
\end{abstract}

Keywords: Wastewater, Reuse, Crops, Vegetables, Fish, Microbiology, Cytotoxicity, allium test, Mitotic index, Chromosomal Aberrations.

\section{Introduction}

Egypt is producing up to $3.0 \mathrm{BCM} / \mathrm{year}$ of STWW, while undergoing $0.73 \mathrm{BCM}$ primary treated wastes. Since 2008, water coverage reached $100 \%$ in all cities, while covered all villages in 2012 . On the other hand, wastewater treatment facilities covered all cities since 2012, while covering about $24 \%$ of existing villages as reported by Holding Company for Water \& Wastewater Authority[1]. For water quality agreement, broad checking programs appropriate where enormous of definite elements were examined for identified pollutants; risk evaluation could be accomplished based on the properties of the separate compounds [2]. Reuse is needed urgently to preserve what water is left and to improve the situation of water shortages. Non-conventional resources such as desalination, wastewater reuse $\&$ drainage water management are proposed to solve the limited rural sanitation with less than $14 \%$. The treated wastewater has to be reused in agricultural sector to compensate the water scarcity and to face the increase of SWWT demand. This trial has been applied in Haram City farm (HCF) to evaluate the reuse of treated wastewater in agricultural sectors, its effect on soil properties and fish farming. Mendoza[3] assessed the influence of treated wastewater (TWW) on merlot grapes and the growth of cabernet sauvignon from Guadalupe Valley, Mexico. He stated that the leaves number/ shoot and the whole biomass improved in plants irrigated with TWW and production/plant of grape was higher by twenty percent. Moreover, the carbohydrates concentration, $\mathrm{pH}$ and organic acids were found in similar conditions as in 
grapes from vines irrigated with wastewater compared to that irrigated by ground water. Water challenges facing Egypt, with inadequate yearly quantity of rain enforced the country to be dependent mainly on the Nile River [4]. The quality of Nile water is quite high from Aswan to Cairo; this quality is highly decreased when the Nile splits into Rosetta and Damietta branches. This is due to the uncontrolled discarding of the agricultural, municipal and industrial[5]. Moreover, stress on the water resources due to population growth associated progresses led to noticeable water pollution [6]. TWW reuse in agricultural purposes is usually companied with evaluation of the water quality. So, many checking programs were crucial to be achieved. Hence many particular ingredients were verified for pollutants recognition, substance-definite, hazard evaluation with respect to genotoxicity can be completed, based on the properties of the separate ingredients[2]. Removal of heavy metals and other toxic pollutants were noticeably detected on using cement kiln dust as coagulant and adsorbent [7]. Domestic wastewater treatment for reuse was evaluated as an example in developing countries by El-Awady [8]. Moreover, results of physicochemical, and biological treatment of wastewater from the meat manufacturing industry as a case study in the 6-Oct. Industrial City was carried out showed a very good destruction of organic pollutants and settling of other suspended solids [9]. On the other hand, photocatalytic- Extended Biological and physico-chemical treatment of autoclave hospital wastewater was carried out with acceptable characteristics for reuse [10]. The anionic dyestuffs from aqueous and effluent liquors were totally removed at their optimum operating conditions on using Cement Kiln Dust [11], while some hazardous anions were removed on using new anion exchange starch[12]. Treatment of wastewater for reuse was carried out using sequential anaerobic/ aerobic treatment technologies for reuse [13,14]. El-Awady \&Ali [15] implemented nonconventional treatment sewage sludge for reuse and applied a catalytic conversion of hydrocarbons via the using of cement kiln dust with high performance. In-addition, the utilization of cement kiln dust in domestic sewage sludge treatment for safe disposal and environmental protection was also widely used [16]. Moreover, Salem et al., [17] enhanced removal of dissolved iron and manganese from nonconventional water resources in delta district-Egypt was carried out and evaluated. The referred case studies were chosen to show that industrial wastewater should be treated before disposal onto sewerage network and to keep wastewater treatment facilities operating properly. Many advantages have been achieved with the decision to usage of wastewater in agriculture [18], and water pollution creates a great health hazard to human, animals, and plants [19]. Among these hazards showed genotoxic and mutagenic effects that have the capacity to induce heritable destructions. It can lead to many health problems and destructions that affected next generations [20]. Many bioassays were accepted for ecological mutagens detection, as those plant assays were quite easy to implement, low-cost and offered wide ranges of hereditary endpoints [21]. Factors such as root growth, shape, incidence of mitosis and irregular cell division used to assess the mutagenicity, genotoxicity and cytotoxicity of ecological pollutant [22]. Many advantages were concluded from Allium test as genotoxicity screening assay [23], whereas root wilting described toxicity [24]. Chemically induced chromosomal aberrations were mainly studied using plant material, such as Allium cepa [25]. Plants that grow in polluted soils when eaten by humans can lead to many health problems [26] like mental retardation, diarrhea, kidney and liver hurt [27]. Allium cepa considered popular edible crop in Egypt, hence this plant has been recommended to be used in the present study.

\section{Materials and Methods}

Materials

Treated wastewater: The secondary treated wastewater (STWW) from 6 October treatment plant outlet is the main source of water inlet to all activities of HCF. The field excrements were carried out in HCF, 6-October City, Giza, Egypt to investigate the effects of TWW in irrigation and dry sludge on the corn growth, quality traits and soil properties after harvesting.

\section{Irrigation water analysis}

STWW from 6 October wastewater treatment plant (WWTP) was the source of HCF inlet. Physico-chemical and biological parameters were analyzed. Figures 1-1 and 1-2 show the irrigated plants of corn crop (Zea Mays L.) Variety Giza352 triple hybrid corn yellow color that used by $14 \mathrm{~kg}$ grains/fed were grown in rows in May, 2014. Grains were planted in hill spaced at $30 \mathrm{~cm}$ at one side of the rows and $70 \mathrm{~cm}$ between rows; two weeks after emergency plants were thinned to one plant/hill. 


\section{Soil analysis}

Soil samples from depths of $0.0-60 \mathrm{~cm}$ were collected and mixed from all plots. The soil and sludge samples were dried, sieved through $2 \mathrm{~mm}$ mesh and kept in plastic bags. All laboratories parameters: $\mathrm{pH}, \mathrm{EC}$, nutrients and heavy metals contents were analyzed according to the American Standard Methods, APHA [28]. The recommended agricultural practices of growing corn plants as: Pre-sowing, $150 \mathrm{~kg} / \mathrm{fed}$ of calcium super-phosphate $\left(15.5 \% \mathrm{P}_{2} \mathrm{O}_{5}\right)$ was applied to the soil. First, Nitrogen (ammonium nitrate 33.5\% at rate of $100 \mathrm{Kg} / \mathrm{fed}$ ) was applied after emergence at five equal doses before the $1^{\text {st }}, 2^{\text {nd }}, 3^{\text {rd }}, 4^{\text {th }}$ and $5^{\text {th }}$ irrigation runs. Potassium sulfate $(48.50 \%)$ was added at two equal doses of $50 \mathrm{~kg} / \mathrm{fed}$. Irrigation was carried out using the Furrow irrigation system, where STWW was added every 7 days. The samples of corn plants were taken at harvesting to investigate the flowing characters per one plant: height $(\mathrm{cm})$, biological yield $(\mathrm{g})$, grain yield $(\mathrm{g})$, straw yield $(\mathrm{g})$. Also Ear: length $(\mathrm{cm})$, diameter $(\mathrm{cm})$, and weight $(\mathrm{g})$, were estimated. Numbers of: rows, No. of grains/ row, 100-grains weight (g) Shelling \% in grains, Protein \% in grains, Starch $\%$ in grains, Humidity $\%$ in grains, Oil $\%$ in grains, protein, starch, oil yields, nutrients and heavy metals grains contents were predicted. Samples from both leaves and fruits of Cucumis sativus that irrigated by STWW were taken then analyzed for heavy metals and nutrients to determine the effect of irrigation on the nutritional status of the plants. A sub-sample of each organic material wet digested with a mixture of percholoric and sulphuric acids, where the digested solution was analyzed for: $\mathrm{N}, \mathrm{P}, \mathrm{K}, \mathrm{Ca}, \mathrm{Mg}, \mathrm{Ni}$, $\mathrm{Pb}, \mathrm{Cd}, \mathrm{Cu}$ and $\mathrm{NO}_{3}$, respectively. Total $\mathrm{N}$ and $\mathrm{P}$ were determined using micro-kjeldahl, while total $\mathrm{K}$ was determined using flame photometer, Perkin Elmer. $\mathrm{Ca}$ and $\mathrm{Mg}$ were measured volumetrically. $\mathrm{Cu}, \mathrm{Ni}, \mathrm{Cd}$, and $\mathrm{Pb}$ in leachates were determined using Atomic Absorption Spectrophotometer, Perkin Elmer, 2380. Nitrate content (\%) in leaves and fruits were determined by extracting $\mathrm{NO}_{3}$ from the samples. All analyses were carried out according to APHA[28].

\section{Cytotoxicity analysis}

Allium cepa bulbs have been used as a test bioassay plant to determine the potential cytotoxicity of STWW if found.

\section{Test materials}

Onion bulbs (Allium cepa) were obtained from local market. The tested water sample was taken from STWW plant to be reused in HCF located at 6-October Governorate.

\section{Allium test}

The Allium test was carried out as described by Rank [29]. Uniform sized onion bulb (1030) g was selected. The outer loose scales were removed and scraped that the apices of the root primordial were exposed. Bulbs were submerged in STWW to about one-quarter the depth of the bulb. It was changed daily and the bottle tanks kept in the dark for the period of the experiment, where tap water was used as a control. Allium cepa bulbs were geminated in glass bottles for $48 \mathrm{hrs}$ to ensure the emergency of roots. Seven bulbs were grown in STWW for 3 days, while water samples were changed daily. The root tips were used for cytogenetic investigation and analysis. Roots were fixed in ethanol: acetic acid (3:1) mixtures for $24 \mathrm{~h}$; hydrolyzed in $1.0 \mathrm{M} \mathrm{HCl}$ for $10 \mathrm{~min}$, then stained with aceto-orcien for $24 \mathrm{~h}$. Root tips were cut-off in a drop of $45 \%$ acetic acid, macerated and squashed [30]. Three replicates were performed for each mentioned treatment and scoring about 2000 cells was done from 5 roots of each replicate. Mitotic Index (MI), frequencies of mitotic phases. RDR (relative division rate) was calculated by the formula [31].

Mitotic abnormalities have been used as endpoints for determination of cytotogenetic effects, while $\% \mathrm{R}$ of MI was calculated as the ratio between number of mitotic cells and total numbers of scored cells. The frequency of mitotic abnormalities was expressed as a percentage in relation to the number of cells in mitosis. The most frequent abnormalities are shown in photomicrographs.

\section{Results and Discussion}

Irrigation water analysis

Physico-chemical and biological properties of

$$
\% \operatorname{RDR}=\frac{(\% \text { of dividing cells in treated sample }-\% \text { of dividing cells in control sample }) \times 100}{100-\% \text { of dividing cells in control bulbs }}
$$

Egypt.J.Chem. 60 , No.6 (2017) 
STWW irrigation water that used to irrigate corn plants are shown in Table 1. It is observed that the values of $\mathrm{BOD}_{5}, \mathrm{COD}$, TSS, TDS, TS and $\mathrm{NO}_{3}$ are less than the safety irrigation ranges.

Heavy metal's concentrations in STWW are listed in Table 2. It is clear that concentrations of $\mathrm{Cr}, \mathrm{Pb}, \mathrm{Co}, \mathrm{Se}, \mathrm{Ni}, \mathrm{Cu}$ and $\mathrm{Zn}$ elements in irrigation STWW are less than the safety limits. It means that these values show low heavy metals contents in STWW if compared with the values of safety levels. It means that the STWW is reliable for this case of irrigation site.

\section{Soil and sludge analysis}

Soil components and texture of the field are shown in Table 3. It shows that the soil can be classified as sandy soil.

Results in Table 4 show the EC and $\mathrm{pH}$ values for sludge as well as soil profile. It is obvious that $\mathrm{pH}$ of the sludge and (soil/sludge) samples were partially acidic. This could be attributed to the accumulation of soluble sulfates and phosphates ions in sludge top soil layer and possibility of organic acids formation due to biodegradation of organic compounds in soils. These results are in accordance with Belyaeva [32] who found lower $\mathrm{pH}$ in the top soil due to adding of bio-solids. Heavy metals in Table 4 indicate that concentrations of $\mathrm{Ni}, \mathrm{Cu}, \mathrm{Pb}$ and $\mathrm{Ni}$ in sludge, soil and soil/sludge are below safety levels. These values point to low heavy metals contents in sludge, soil and soil/ sludge in comparable with safety levels. Similar results were observed by Ferrara[33].

Corn grain yield and quality traits

Data in Table (5) show that the maximum grain, starch, protein and oil yields/plant are: $151.1 ; 98.82 ; 19.34$ and 7.71 , respectively. It was achieved due to plant growth as plant height, biological and straw yield/plant, ear length, ear diameter, ear weight, no. of rows in ear, no. of grains/ row and 100-grains weight. Protein, starch and oil $\%$ in grains were measured when using STWW for irrigation on mixing sludge to soil.

On the other hand; the results in Table 6 indicate that the concentrations of $\mathrm{Pb}, \mathrm{Ni}, \mathrm{Cu}$ and $\mathrm{Cd}$ in corn grains are less than the values of safety levels. It indicates low contents of heavy metals in corn grains as compared with safety rates. This means that the produced corn grains irrigated by STWW are suitable for edible consumption.

Results revealed that the proportion of elements: $\mathrm{N}, \mathrm{P}, \mathrm{K}, \mathrm{Ca} \& \mathrm{Mg}$ in leaves and fruits option are in the natural rates of plant. As for the heavy elements; $\mathrm{Cd}, \mathrm{Pb}, \mathrm{Cu}, \mathrm{Ni}$ are also allowed in the plant borders, while nitrates content is considered high for the plant eaten fresh Table 7. Therefore precaution should be paid to the cultivation of vegetables assigned fresh such as lettuce and peppers where nitrate accumulates in the part eaten crops which affects human health and spreading diseases.

\section{Fish examination and evaluation}

Results showed that the parasitological examination revealed that no parasitic cysts were detected in the skin, gills and intestine, respectively. The bacterial infections of the collected fish showed no bacterial strains were isolated from the fish tissues. Results showed

TABLE 1. Physico-chemical and biological properties of treated wastewater for reuse of HCF *

\begin{tabular}{lccc}
\hline Characters & Unit & Value & Safety limit \\
\hline pH- value & $==$ & 8.25 & -- \\
Chemical oxygen demand (COD) & $\mathrm{mg} / 1$ & 12 & 80 \\
Chemical oxygen demand $\left(\mathrm{BOD}_{5}\right)$ & $\mathrm{mg} / 1$ & 6 & 40 \\
Dissolved oxygen (DO) & $\mathrm{mg} / 1$ & 2.5 & -- \\
Total suspended solids (TSS) & $\mathrm{mg} / 1$ & 5 & 40 \\
Total dissolved solids (TDS) & $\mathrm{mg} / 1$ & 309 & 2000 \\
Total solids $(\mathrm{TS})$ & $\mathrm{mg} / 1$ & 314 & -- \\
Phosphate $\left(\mathrm{PO}_{4}\right)$ & $\mathrm{mg} / 1$ & 0.1 & -- \\
Nitrites $\left(\mathrm{NO}_{2}\right)$ & $\mathrm{mg} / 1$ & 0.6 & -- \\
Nitrates $\left(\mathrm{NO}_{\mathrm{a}}\right)$ & $\mathrm{mg} / 1$ & 6.2 & 55 \\
Ammonia $\left(\mathrm{NH}_{4}\right)$ & $\mathrm{mg} / 1$ & 0.2 & -- \\
Nitrogen $(\mathrm{N})$ & $\mathrm{mg} / 1$ & 1.22 & -- \\
\hline
\end{tabular}

* Average of three successive runs

Egypt.J.Chem. 60 , No.6 (2017) 
TABLE 2. Heavy metals content of irrigation STWW of HCF * .

\begin{tabular}{llcc}
\hline Heavy metals & Unit & Value & Safety limit \\
\hline Chromium $(\mathrm{Cr})$ & $\mathrm{mg} / \mathrm{l}$ & $<0.01$ & 0.1 \\
Lead $(\mathrm{Pb})$ & $\mathrm{mg} / \mathrm{l}$ & $<0.01$ & 5 \\
Cobalt $(\mathrm{Co})$ & $\mathrm{mg} / \mathrm{l}$ & $<0.01$ & 0.05 \\
Selenium $(\mathrm{Se})$ & $\mathrm{mg} / 1$ & $<0.005$ & $==$ \\
Nickel $(\mathrm{Ni})$ & $\mathrm{mg} / \mathrm{l}$ & $<0.01$ & 0.2 \\
Copper $(\mathrm{Cu})$ & $\mathrm{mg} / \mathrm{l}$ & $<0.01$ & 0.2 \\
Zink $(\mathrm{Zn})$ & $\mathrm{mg} / 1$ & $<0.01$ & 2 \\
\hline
\end{tabular}

* Average of three successive runs

TABLE 3. Soil fractions and texture .

\begin{tabular}{cccc}
\hline \% Sand & \% Silt & \% Clay & Soil Texture \\
\hline 93 & 4 & 3 & Sandy \\
\hline
\end{tabular}

TABLE 4. Heavy metals concentration with $\mathrm{pH}, \mathrm{EC}$ in soil profile and sludge *.

\begin{tabular}{lcccccc}
\hline Sample/ Parameter & $\mathbf{p H}$ & $\mathbf{E C}$ & $\mathbf{N i}$ & $\mathbf{C u}$ & $\mathbf{P b}$ & $\mathbf{C d}$ \\
\hline Unit & $==$ & $\mathrm{mmhos} / \mathrm{Cm}$ & $\mathrm{mg} / \mathrm{g}$ & $\mathrm{mg} / \mathrm{g}$ & $\mathrm{mg} / \mathrm{g}$ & $\mathrm{mg} / \mathrm{g}$ \\
Sludge & 5.7 & 1.61 & 1.29 & 0.31 & 0.53 & 0.22 \\
Soil & 7.5 & 1.03 & 1.24 & 0.00 & 0.25 & 0.21 \\
Soil/sludge & 6.8 & 0.17 & 2.04 & 0.07 & 1.63 & 0.28 \\
Safety levels & -- & -- & 420 & 1500 & 300 & 39 \\
\hline
\end{tabular}

* Average of three successive runs

TABLE 5. Morphological, grain yield, and quality traits of corn grown in Harm city farm *

\begin{tabular}{|c|c|c|c|c|c|}
\hline Characters & Unit & Value & Characters & Unit & Value \\
\hline Plant height & $\mathrm{Cm}$ & 137.00 & 100-grains weight & $\mathrm{g}$ & 27.30 \\
\hline Biological yield/plant & $\mathrm{g}$ & 305.50 & Shelling in grains & $\%$ & 49.46 \\
\hline Grain yield/ plant & g & 151.10 & Protein in grains & $\%$ & 12.80 \\
\hline Straw yield/plant & $\mathrm{g}$ & 154.40 & Starch in grains & $\%$ & 65.40 \\
\hline Ear length & $\mathrm{Cm}$ & 16.50 & Humidity in grains & $\%$ & 08.60 \\
\hline Ear diameter & $\mathrm{Cm}$ & 04.65 & Oil in grains & $\%$ & 05.10 \\
\hline Ear weight & $\mathrm{g}$ & 177.50 & Protein yield & $\mathrm{g}$ & 19.34 \\
\hline No. of rows in ear & $=$ & 18.00 & Starch yield & $\mathrm{g}$ & 98.82 \\
\hline No. of grains/ row & $=$ & 36.00 & Oil yield & $\mathrm{g}$ & 07.71 \\
\hline
\end{tabular}

* Average of three successive runs

TABLE 6. Heavy metals content in corn grains irrigated with STWW with sludge treatment.

\begin{tabular}{lcccc}
\hline \multirow{2}{*}{ Treatment } & \multicolumn{2}{c}{ Results $(\mathbf{m g} / \mathbf{g})$} & $\mathbf{P b}$ & $\mathbf{C d}$ \\
\hline Corn grains & $\mathbf{N i}$ & $\mathbf{C u}$ & 0.52 & 0.25 \\
Safety rates & 1.39 & 0.00 & 300 & 39 \\
\hline
\end{tabular}


TABLE 7. Indications of NPK and heavy metals.

\begin{tabular}{ccccccccccc}
\hline Sample & $\mathbf{T K N}$ & $\mathbf{P O}_{4}$ & $\mathbf{K}$ & $\mathbf{N O}_{3}$ & $\mathbf{C a}$ & $\mathbf{M g}$ & $\mathbf{C d}$ & $\mathbf{P b}$ & $\mathbf{C u}$ & $\mathbf{N i}$ \\
\hline 1 & 3.84 & 0.38 & 3.48 & 850 & 0.80 & 88.5 & 0.11 & 0.83 & 0.04 & 0.70 \\
2 & 3.86 & 0.34 & 3.43 & 844 & 0.84 & 84.5 & 0.13 & 0.97 & 0.03 & 0.66 \\
3 & 2.99 & 0.41 & 3.77 & 823 & 0.82 & 87.4 & 0.14 & 0.89 & 0.02 & 0.78 \\
4 & 3.24 & 0.42 & 3.65 & 853 & 0.79 & 84.7 & 0.12 & 0.72 & 0.06 & 0.75 \\
5 & 3.67 & 0.44 & 3.44 & 845 & 0.77 & 83.8 & 0.12 & 0.83 & 0.03 & 0.70 \\
\hline
\end{tabular}

also that kidneys, livers and all cultivated plates revealed no observed bacterial colonies. In general, the clinical abnormalities of the examined Tilapia revealed apparently healthy fish. Histopathological studies of the gills appeared normally consist of 4 gill arches on either side or extending from floor to roof of the buccal cavity. Two holo-branches rows of filaments called primary lamellae project from the posterior edge of each gill arch. Anterior edges of the arches comprise gill rakers which keep the delicate filaments and support in food acquisition. Figure 1 shows no identified histopathological changes. The skin of Tilapia fish was relatively appeared normal consisting of an epidermis and dermis. The epidermis is several cells thick, made of stratified epithelium, a superficial epithelial layer, middle Malpighian cells, and a basal cuboidal to columnar cell layer that rests on a basement membrane. Big ovoid or cylinder cells with homogenously eosinophilic cytoplasm, and one or more centrally positioned nuclei, corresponding to the so-called club cells were dispersed at diverse levels in the epidermis. Mucous cells were seen superficially. Lipophores and melanophores may lie under the epidermis and at different levels of the dermis. The dermis consisted of collagenous connective tissue fibers that can be differentiated into upper stratum sponginum and inner stratum compactum. Scale pockets were found at different intervals in the skin. The dermis was bounded internally by a single layer of cells which separated from the deep hypodermis. The skeletal muscles, myomeres, are separated from each other by collagenous connective tissue septa as represented in Figs 2-1:2-4. Results showed that livers of some fish suffered from fatty changes. The hepatic cells lost their staining affinity because swollen and the cells were compressed against each others. These changes may be normal because the liver acted as fat storage, as indicated in Fig 2. Examination Egypt.J.Chem. 60 , No.6 (2017) of the head kidney revealed that it was consisted of nephrons and interstitial lymphoid tissue. The consistent picture in the examined cases and abnormal changes were not commonly seen (Fig. 2-4). Spleen revealed no changes could be seen.

\section{Cytotoxicity analysis}

\section{Macroscopic parameters}

The Allium roots length were measured every 24 hours for 3 days. The records are shown in Table 8, where in both samples and control no significant differences were recorded as well as the morphology of roots which can be used for detecting the toxicity of water, where they appeared healthy with normal ends as shown in Fig. 3.

\section{Microscopic parameters}

Mitotic index, RDR and phase index (MI)

Results showed non-significant change after the treatment of onions bulbs with the treated STWW sample when compared with control. The RDR gave positive value and Aberrations index (AI). Chromosomal aberrations show non-significant change. RDR had recorded a positive value. Phase index showed nonsignificance change, all as shown in Table 9.

\section{Chromosomal aberrations}

Also, chromosomal aberrations percentage doesn't change significantly between water sample and control and almost all examined cells were normal as shown in Table 8. Some aberrations were recorded but in the save limits. Micronucleus as well as stickiness showed the most frequent chromosomal abnormality types (Fig 4).

In countries, where intended reusing wastewater discharges in husbandry, evaluation and conservation of its feature were crucial [34] . In this study cytotoxicity for water quality testing decides if STWW is safe for farm irrigation. Factors as root growth and shape, occurrences of mitosis and irregular cell division can be used to assessment 

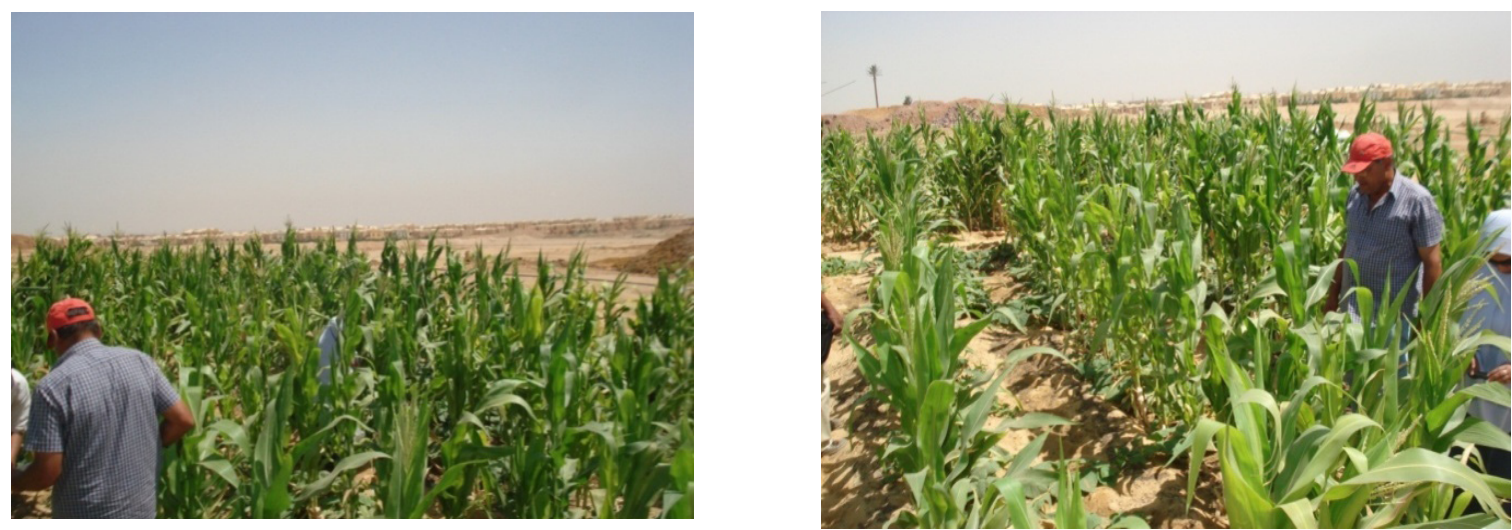

Fig. 1-1

Fig. 1-2

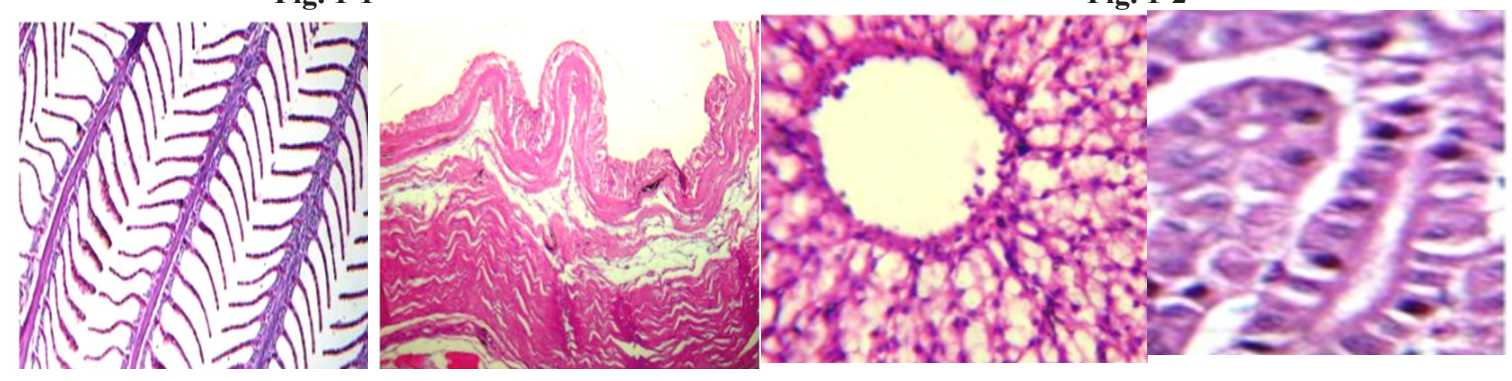

Fig. 2-1. Gills showing normal primary and secondary lamellae structure (H\&E, X 400), Fig. 2-2. Skin Showing normal structural consisting of an epidermis and dermis, the epidermal layer consisting of several cell layers, (H\&E, X 400), Fig. 2-3. Liver showing fatty degeneration (H\&E, X 400) and Fig. 2-4. Kidneys showing normal structure of renal tubules (H\&E, X 400).

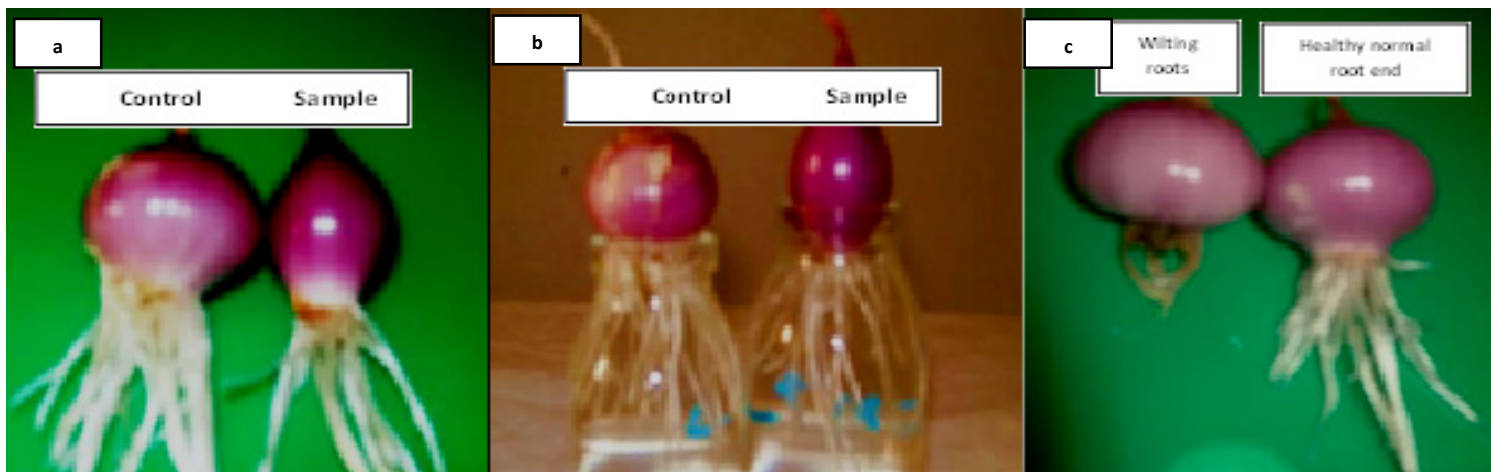

Fig. 3. Plate 1. (a-b) Root length of Allium cepa bulbs after 3 days of treatment and (c): Morphology of Alliumcepa roots after treatment.

TABLE 8. Results of treated root tips of Allium cepa with TWW showing root length in 3 days by millimeter (mm).

\begin{tabular}{lcccc}
\hline & & & \\
\cline { 1 - 3 } \cline { 3 - 4 } \cline { 3 - 4 } Treatment & & Root lengths $(\mathbf{m m})$ & \\
Control sample & 24 Hours & 48 Hours & Hours \\
STWW & 20 & 39 & 68 \\
\hline
\end{tabular}

TABLE 9. Results of treated root tips of Allium cepa with tested water sample showing mitotic index (M.I), RDR, Phase index and Chromosomal aberrations. (Mean \pm SD).

\begin{tabular}{cccccccc}
\hline \multirow{2}{*}{ Treatment } & \multirow{2}{*}{ \% M.I. } & \multirow{2}{*}{ RDR } & Prophase & Metaphase & Anaphase & Telophase & Chromosomal \\
& & & & & Mberrations \\
\hline $\begin{array}{l}\text { Control } \\
\text { sample }\end{array}$ & $12.56 \pm 0.41$ & - & $20.12 \pm 0.19$ & $30.17 \pm 0.86$ & $28.12 \pm 0.23$ & $20.59 \pm 0.67$ & $0.63 \pm 0.60$ \\
STWW & $12.82 \pm 0.58$ & 2.07 & $19.75 \pm 0.61$ & $29.10 \pm 0.85$ & $30.05 \pm 0.36$ & $21.10 \pm 0.41$ & $0.72 \pm 0.59$ \\
\hline
\end{tabular}





Plate 2. Normal mitosis (a) interphase, (b) prophase, (c) metaphase, (d) anaphase, (e) telophase, (f) interphase with micronucleus (g) abnormal prophase (h) sticky metaphase, (i) bridge at anaphase and (j) abnormal telophase.

the mutagenicity, genotoxicity and cytotoxicity of ecological contaminant [35] . Cytotoxicity of any compound could be determined by its capability to hinder or improve cell proliferation. Pollutants in water may interfere with mitotic index and lead to induce chromosome abnormality [36] . Results achieved no marked decrease in root length, root shape and root growth when compared with its control. It provides also, evidence of the tested sample neither inhibit root growth nor cause growth retardation. Allium test exhibited more sensitivity presented by severe inhibition in mitotic activity, increase of chromosomal aberrations percentage. In spite of the Allium test seem to be efficient in detecting genotoxic potential of water pollutants, each root wilting and plant growth retardation was followed by reduction of mitotic activity and existence of chromosomal abnormality [37]. Mitotic index used as a pointer of cell proliferation which measures the level of cells in the mitotic stage of the cell cycle. Hence, cellular death could be understood as the reduction in the mitotic index of A. cepa meristematic cells [38] . The mitodepressive effect was frequently used in locating cytotoxicity [39]. In this research, treated cells of $A$. cepa root tips with treated wastes showed no changes in mitotic index when compared with control. There were no significant alterations between treatment and control plants. This may cause that tested water sample was free from cytotoxicity elements. Chromosome abnormality analysis allowed to evaluate genotoxic properties and to estimate the clastogenic and aneugenic actions [38]. The chromosomal aberrations could be attributed to the obstruction of DNA synthesis or inhibition of spindle fiber development [40] . In this study, the chromosome abnormality observed were chromosome stickiness, bridges and micronucleus in non-significant values. These aberrations may be because of the result of treatment on the spindle development and thus lead to disorders of cellar division. Chromosomal found in this research not serious count. The impacts of using TWW due water shortage or as a fertilizer must be in careful and cushions ways. Nevertheless the positive outcome in Allium test must be used as an indicator of warning as a negative impact to environment and human health. Similarly, the incidence of mutagenic combinations in STWW needs additional handling to eliminate them.

\section{Conclusion}

Treated effluent offers significant water demand for irrigating in rural farms. Heavy metals concentration in STWW lay in irrigation acceptable limits, while: C, N, P are fulfilling their ratios for plant growth and exhibited good growth. Metals concentrations in roots, stems, leaves and seeds were within the permissible range. Parasitological examination of fish showed noticeable vitality, with no detected parasitic cysts in the skin, gills and intestine. STWW has no mutagenicity or cytotoxicity effects. It is recommended to avoid 
direct irrigation of fresh vegetables with this type of TWW. The tested water sample didn't change mitotic index of the bioassay plant tissues and not stimulate specific type of chromosomal aberrations as well as percentage of chromosomal aberrations. Morphology and length of plant roots look normal and healthy. Hence STWW sample has no mutagenicity or cytotoxicity effects, but it should be used carefully for restricted irrigation.

\section{References}

1. Holding Company for Water \& Wastewater Authority (HCWWA), Report (2017).

2. Bobeldijk, I., Brandt, A., Wullings, B., and Noij, Th., High performance liquid chromatographyTox Print: chromatographic analysis with a novel genotoxicity detection, Journal of Chromatography A 918 (2), 277-291 (2001)

3. Mendoza-Espinosa, G. L., A. Cabello-Pasini, V. Macias- Carranza, W. Daessle-Heuser, V. M. OrozcoBorbón and Quintanilla-Montoya, L. A. The effect of reclaimed wastewater on the quality and growth of grapevines. Water Science and Technology, 57( 9), 2008, pp. 1445-1450. doi:10.2166/wst.2008.242. (2008)

4. Agrama, A.A., and El-Sayed, E.A., Assessing and mapping water quality (case study: western delta -Egypt. International Water Technology Journal, IWTJ. 3(3), 158-169 (2013).

5. World Bank, Country Environmental Analysis (1992-2002), Arab Republic of Egypt, Water and Environment Department. The Middle East and North Africa Region, World Bank (2005)

6. AWF (African Water Facility), Comprehensive Study and Project Preparation for the Rehabilitation of the Nubaria and Ismailia canals, Appraisal Report (2007)

7. El-Awady M. H., and T. M. Sami, Removal of heavy metals from wastewater using cement kiln dust. Bulletin of Environmental Contamination \& Toxicology. 59(4), October, pp. 603 - 610, (1997)

8. El-Awady M.H. "A reliable approach for sewage treatment in developing countries". Journal of The Egyptian Society of Engineers,37(1), 42 - 45 (1998)

9. El-Awady M. H. Treatment of wastewater from the meat manufacturing industry- case study. The International Journal of Environmental Studies, $O P A, \mathbf{5 6}, 345-356,(1999)$

10. El-Awady M.H., Ali S.A., Sami T.M., Shaltout F.M. and Negm M.S., Photocatalytic- extended biological and physico-chemical treatment of autoclave hospital wastewater for reuse, Ain Shams Journal of Civil Engineering (ASJCE), ISSN 1687 - 8590, Vol. 1, March, (2008)

11. Ibrahim N. A, El-Awady M. H. , and Abu Shosha, M. H. Removal of anionic dyestuffs from aqueous and effluent liquors using cement kiln dust. Colourage, XLV(2), 29 - 34, Feb.(1998).

12. Abou-Shosha M.H, M. H. El-Awady, and N.A. Ibrahim, "New anion exchange starch for the removal of some hazardous anions. Colourage, XLIV (9), 34- 38, September (1997)

13. Abdel-Wahaab R. and M.H. El-Awady, "Anaerobic/aerobic treatment of meat processing wastewater". The International Journal for All Environmental Professionals [The Environmentalist], 19, 0960- $3115 *$ Kluwer Academic Publishers, 61 - 65 (1999)

14. El-Awady M.H. and R.A. Wahaab, "Agro-Industry wastewater treatment. Environmental Technology, 20, pp 1001- 1004, Selper Ltd. (1999)

15. El-Awady M.H and Ali.,S.A. Non conventional treatment sewage sludge using cement Kiln Dust for Reuse and Catalytic Conversion of Hydrocarbons, Earth \& Environmental Science, The Environmentalist, DOI, 10.1007/s 10669012-9411-8, ISSN 0251-1088, (2012)

16. El-Awady M.H., Abo-El-Einein S.A \& Anwar Sh.M, Utilization of cement kiln dust in domestic sewage sludge treatment for safe disposal and environmental protection, $J$ Environ Sci, Institute of Environmental Studies and Research, Ain Shams Univ., 33, 2 (2016)

17. Salem M., El-Awady M.H. \& Amin E. ,Enhanced removal of dissolved iron and manganese from nonconventional water resources in delta district, Egypt, Science Direct, Energy Procedia, 310, 1600-1611(2012)

18. Abdel Migid, H.M., and Abdelrahman H.M.H., Phyto-genotoxicity Assessment of Sewage Water for Agriculture Applications. Research Journal of Pharmaceutical, Biological and Chemical Sciences. 4(2), 511-529 (2013)

19. Al-Dulaimi, R.I., Ismail, N.B., and Ibrahim, M. H., The effect of industrial wastewater in seed growth rate: A Review. International Journal of Scientific and Research Publications, 2 (3), 1-4 (2012)

20. Ribeiro L.R., Teste do micronu' cleoemmedula o' ssea de roedores in vivo, in: L.R. Ribeiro, D.M.F. Salvadori, E.K. Marques (Eds.), Mutagenese Ambiental, Ulbra, Canoas, pp. 201-219 (2003)

21. Grant, W.F., Higher plant assays for the detection of chromosomal aberrations and gene mutation

Egypt.J.Chem. 60 , No.6 (2017) 
-a brief historical background on their use for screening and monitoring environmental chemicals. Mutat. Res. 426, 107-112 (1999)

22. Amin, A.W., Cytotoxicity testing of sewage water treatment Using Allium cepa chromosome aberrations assay. Pakistan Journal of Biological Sciences, 5(2), 184-188 (2002).

23. Cresencio, C., Cabuga, Jr., J.J.Z., Abelada, R.R.Q., Apostado, B.J.H., Hernando, J.E.C., Lador, O., L., Obenza, P., C.J.R., Presilda, and H.C. Havana, Allium cepa test: An evaluation of genotoxicity. Proceedings of the International Academy of Ecology and Environmental Sciences, 7(1), 12-19 (2017).

24. Odeigah, P.G.C., Nurudeen, O., and Amund, O.O., Genotoxicity of oil field wastewater in Nigeria. Hereditas 126, 161 - 167 (1997).

25. Levan, A., Effect of colchicine on root mitosis in Allium. Hereditas, 24, 471486 (1938).

26. Wahid, A., S., Ahmad, S., Rehman, and S.S., Ahmad, Growth and biochemical status of wheat seedling treated with industrial effluents. Biologia, 50(1), 91-98 (2004).

27. Uzair, M., M., Ahmad, and K., Nazim, Effects of industrial waste on seed bank and growth of wild plants in Dhabeji area, Karachi, Pakistan. Pak. J. Bot., 41(4), 1659-1665 (2009).

28. American Public Health Association APHA, Standard Methods for the Examination of Water and Wastewater book, 22nd edition,724 pages (2012)

29. Rank, J., Lopez, L.C., Nielsen, M.H., and Moretton, J., Genotoxicity of maleic hydrazide, acridine and DEHP in Allium cepa root cells performed by two different laboratories. Hereditas 136,13-18 (2002)

30. Sharma, A.K., and Sharma, A., Chromosome Techniques Theory and Practice. 3rd. ed. Butterworth and Co. Publishers ltd., 145-150 (1980).

31. Hoda, Q., Bose, S., and Sinha, S.P., Vitamin $\mathrm{C}$ mediated minimization of Malathion and Rogor induced mito-inhibition and clastogeny. Cytologia, 56, 389-397 (1991).

32. Belyaeva, N.O., J.R., Haynes, and C.E., Sturm, "Chemical, physical and microbial properties and microbial diver-sity in manufactured soils produced from co-composting green waste and biosolids. Waste Management, 2012 Dec; 32(12), 2248-2257. doi:10.1016/j.wasman. 2012.05.034.

33. Ferrara L., Iannace M., , Patelli M.A. and Arienzo M.,Geochemical survey of an illegal waste disposal site under a waste emergency scenario (Northwest Naples, Italy)," Environmental Monitoring and Assessment, Mar; 185(3), 26712682 (2013).

Egypt.J.Chem. 60 , No.6 (2017)
34. Nielsen, M.H., and Rank, J., Screening of toxicity and genotoxicity in wastewater by the of the Allium test. Hereditas 121, 249-254 (1994).

35. Dourado, P.L.R., M.P., da Rocha, L M., Roveda, J.L.R., Junior, L.S., Cândido, C.A.L., Cardoso, M.A., Morales, M., K.M.P., de Oliveira, and A.B., Grisolia, Genotoxic and mutagenic effects of polluted surface water in the Midwestern region of Brazil using animal and plant bioassays. Genetics and Molecular Biology, 40(1), 123-133 (2017)

36. Abdel-Rahman, H.M.H., H.M., Abdel Migid, S.A., Attia and A.A., Rizkalla, Cytogenetical, Biochemical and Chemical Analytical Studies for Assessment of the Water Quality of Nile Water Using Three Bioassays. Middle East Journal of Applied, 5(4), 112-124 (2015).

37. Ping, K.Y., Darah, I., Yusuf, U.K., Yeng, C., and Sasidharan, S., Genotoxicity of euphorbiahirta: an Allium cepa assay. Molecules, 17 (7), pp. 77827791 (2012).

38. Smaka-Kincl, V., Stegnar, P., Lovka, M., and Toman, M., The evaluation of waste, surface and ground water quality using the Allium test procedure. Mut. Res., 368, 171-179 (1996).

39. Scheible, O., M., Casey, and A., Forndran., Ultraviolet disinfection of wastewaters from secondary effluent and combined sewer overflows. U.S. Environmental Protection Agency, Washington, D.C., EPA/600/2-86/005 (NTIS PB86145182), (1985).

40. Environment Protection Agency; EPA, U.S, the risk assessment guidelines of 1986 (1986).

(Received 24/ 7 / 2017; acecpted 24/ 9 / 2017) 


\title{
تأثثر مياه الصرف المعالجة على دورة الحياة في مزرعه ريفيه، (مصر)
}

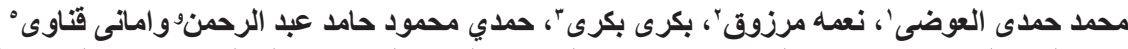



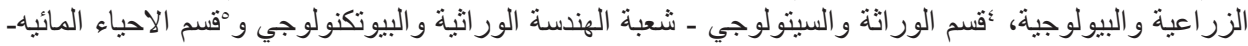

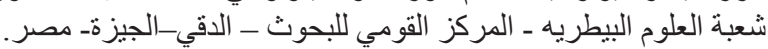

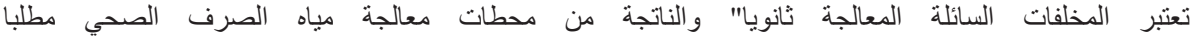

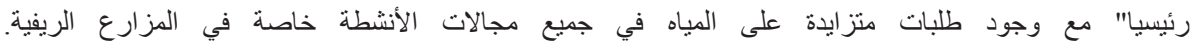

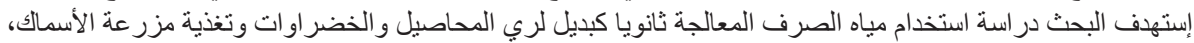

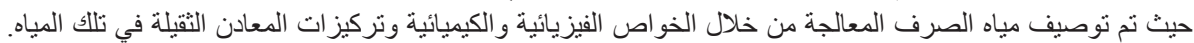

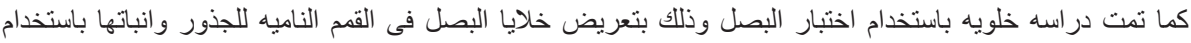

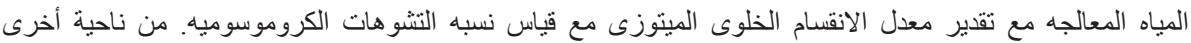

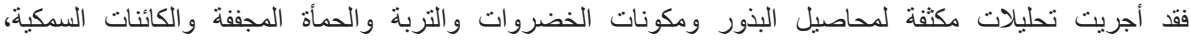

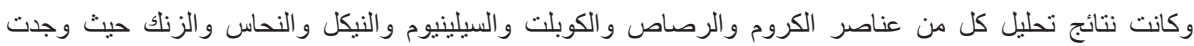

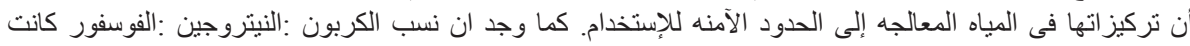

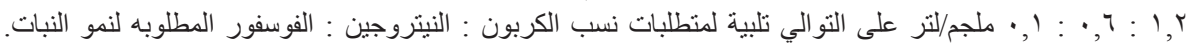

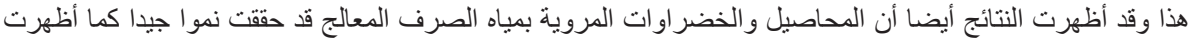

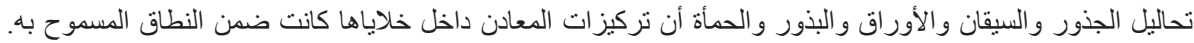



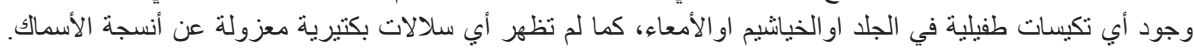

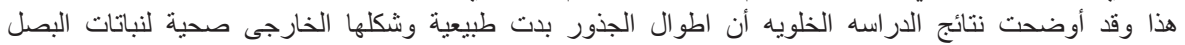

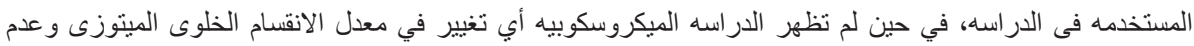

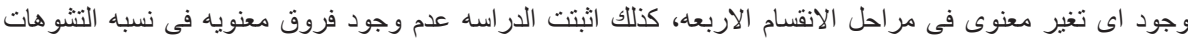

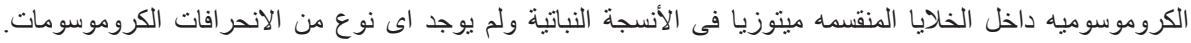

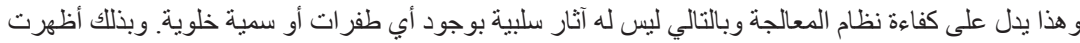

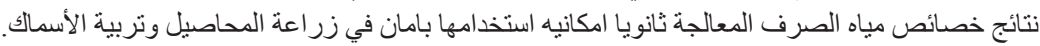

